\title{
Correction to: Parameterized Complexity of Min-Power Asymmetric Connectivity
}

\author{
Matthias Bentert ${ }^{1} \cdot$ Roman Haag $^{1} \cdot$ Christian Hofer $^{1}$. \\ Tomohiro Koana $^{1}$ • André Nichterlein ${ }^{1}$
}

Published online: 16 August 2021

(C) The Author(s) 2021

\section{Correction to: Theory of Computing Systems (2020) 64:1158-1182 https://doi.org/10.1007/s00224-020-09981-w}

The article Parameterized Complexity of Min-Power Asymmetric Connectivity, written by Matthias Bentert, Roman Haag, Christian Hofer, Tomohiro Koana, André Nichterlein was originally published electronically on the publisher's internet portal on 23 May 2020 without open access. After publication in volume 64, issue 7, pages 11581182, the author decided to opt for Open Choice and to make the article an Open Access publication. Therefore, the copyright of the article has been changed to $(C)$ The Author(s) 2021 and the article is forthwith distributed under a Creative Commons Attribution 4.0 International License (https://creativecommons.org/licenses/by/4.0/), which permits use, sharing, adaptation, distribution and reproduction in any medium or format, as long as you give appropriate credit to the original author(s) and the source, provide a link to the Creative Commons licence, and indicate if changes were made. The images or other third

The online version of the original article can be found at https://doi.org/10.1007/s00224-020-09981-w

Matthias Bentert

matthias.bentert@tu-berlin.de

Roman Haag

roman.haag@campus.tu-berlin.de

Christian Hofer

hofer@campus.tu-berlin.de

Tomohiro Koana

tomohiro.koana@tu-berlin.de

André Nichterlein

andre.nichterlein@tu-berlin.de

1 Algorithmics and Computational Complexity, Faculty IV, TU Berlin, Berlin, Germany 
party material in this article are included in the article's Creative Commons licence, unless indicated otherwise in a credit line to the material. If material is not included in the article's Creative Commons licence and your intended use is not permitted by statutory regulation or exceeds the permitted use, you will need to obtain permission directly from the copyright holder. To view a copy of this licence, visit http:/creativecommons.org/licenses/by/4.0. Open access funding enabled and organized by Projekt DEAL.

The original article has been corrected.

Publisher's Note Springer Nature remains neutral with regard to jurisdictional claims in published maps and institutional affiliations. 